\title{
Corporate Social Responsibility Impact on Financial Performance: a Case for the Metallurgical Industry
}

\author{
ALEKSEY MINTS \\ Department of Finance and Banking \\ Pryazovskyi State Technical University \\ Universytets'ka 7, 87500, Mariupol, \\ ORCID ID: https://orcid.org/0000-0002-8032-005X \\ UKRAINE \\ EVELINA KAMYSHNYKOVA \\ Department of Economics of an Enterprise \\ Pryazovskyi State Technical University \\ Universytets'ka 7, 87500, Mariupol, \\ ORCID ID: https://orcid.org/0000-0003-1835-9786 \\ UKRAINE \\ DMYTRO ZHERLITSYN \\ Department of Economic Cybernetics \\ National University of Life and Environmental Sciences of Ukraine, \\ Heroiv Oborony Str.15, 03041, \\ ORCID ID: https://orcid.org/0000-0002-2331-8690 \\ UKRAINE \\ KATERINA BUKRINA \\ Department of Economic Theory and Entrepreneurship \\ Pryazovskyi State Technical University, \\ ORCID ID: https://orcid.org/0000-0002-9946-781X \\ UKRAINE \\ ANNA BESSONOVA \\ Department of Economics of an Enterprise \\ Pryazovskyi State Technical University \\ Universytets'ka 7, 87500, Mariupol, \\ ORCID ID: https://orcid.org/0000-0003-4747-1187 \\ UKRAINE
}

\begin{abstract}
Assessing the impact of methods of corporate social responsibility management on financial performance is one of the key aspects to implement strategic management into practices. There are contradictory results of this impact's study in the literature due to the difference in the applied methods of measuring variables, errors in models etc. The available literature is still inconclusive about this aspect, in particular, for the metallurgical industry, which plays a significant role in Ukrainian and world economy. The purpose of the paper is to evaluate the impact of corporate social responsibility on the company financial performance and to determine the financial efficiency of socially responsible initiatives for the metallurgical industry in particular. It proposes methodology for assessing the impact of corporate social responsibility on the corporate financial performance, and it uses data from a socially oriented balanced scorecard. The research methodology includes correlation and regression analysis with panel data techniques based on data from a balanced scorecard for a sample of four dominant market participants in the Ukrainian metallurgy in 20102018. Authors assess the level of corporate social responsibility by indicators of four perspectives, such as: internal processes, learning and growth, environmental, and relational perspective that characterizes the level of
\end{abstract}


satisfaction of various stakeholder groups with the company's activities in the field of corporate social responsibility. The initial data for the analysis have been taken from the financial and non-financial statements and results of expert assessment. The study uses linear and panel regression models with fixed and random effects in order to demonstrate the impact of four independent variables (internal processes, learning and growth, environmental, and relational perspectives) on the financial perspective as a dependent variable. The

panel effects made it possible to obtain more accurate model's parameters compared to simple linear regression model. The empirical finding from the study illustrates a strong and statistically significant relationship between the relational perspective, which is a corporate social responsibility indicator, and the financial perspective in the socially oriented balanced scorecard. This means that the costs of creating and maintaining a positive image of metallurgical companies are fully justified by improving their bottom line. Future research directions compare the effectiveness of statistical methods evaluating the impact of corporate social responsibility on the company financial performance with alternative methods, e.g. data mining techniques, in terms of forecasting accuracy.

Key-Words: - corporate social responsibility; corporate financial indicators; balanced scorecard; correlation analysis; panel regression, metallurgical industry

Received: September 22, 2020. Revised: April 14, 2021. Accepted: April 19, 2021. Published: April 262021.

\section{Introduction}

Today the importance of socially responsible initiatives in the corporate governance system has grown from an optional component to an integral element of strategic management. The issues of assessing the social and financial consequences of socially responsible business practices and their relationship are frequent topics of discussion in the research literature [14; 23].

Milton Friedman (1970) argued that corporations are socially responsible only for increasing profits and creating shareholders' wealth $[5 ; 17 ; 20 ; 28]$. Stakeholder theory, which gained popularity in the 1980s through the works of R. Edward Freeman, has shifted research focus to responsibility to multiple stakeholders and endorsing social performance as a necessary feature to increase organizational business legitimacy $[7 ; 11 ; 27]$. Stakeholder theory has led to awareness of the necessity to implement corporate social responsibility strategies both meeting the needs of multiple stakeholder groups and maximizing shareholder wealth [19]. Therefore, implementation of socially responsible initiatives that improve the organizational climate, promote innovations and contribute employee productivity can also be financially beneficial for the companies [6]. In other words, corporate social responsibility is a prerequisite for protecting the bottom line [9].

Research examining the relationship between corporate social responsibility and the financial performance of organizations has been conducted over the past 40 years $[10 ; 22]$. Taking into account conflicting research results, the lack of consensus among scientists regarding the consideration of industry specifics and the company size, the selection of methods and instruments for measuring corporate social responsibility and financial indicators [8], further research on this topic is required

\section{Problem Formulation}

Assessing the impact of corporate social responsibility on company performance, especially financial performance, is of particular importance in corporate governance. Despite numerous studies conducted from the early 1970 s to the present, it is a controversial issue whether corporate socially responsible initiatives contribute to the improvement or deterioration of financial performance for all companies and for all activities $[12 ; 17]$.

There are positive, negative, mixed and conflicting research results in the literature. Some results confirmed the positive impact of corporate social responsibility activities on the company's bottom line $[15 ; 30 ; 32]$, which confirms the need to support investment in this area for sustainable economic growth. A number of studies point to a negative relationship between corporate social responsibility and corporate financial performance [31]. This is consistent with the view that social responsibility entails additional operating and investment costs and reduces profitability [33]. Such conclusions do not necessarily indicate the need to 
abandon socially responsible activities due to a decrease in financial performance, since many managers believe it is important to be a good corporate citizen, even if it is done at the expense of shareholders [33].

Differences in research results arise from different methods of measuring variables, errors in models and research methods used, and inability to solve the problem of endogeneity [18]. In addition, a "stakeholder mismatch" issue or focusing on criteria for company size or strategy applied by managers in a particular industry group can cause this [28].

A number of sources confirm the increased validity and accuracy of research by focusing on a single industry [31].

The banking and the financial sector are leading industries that become objects of studying the relationship between corporate social responsibility and financial performance at the corporate level [13]. However, the existing literature is still inconclusive about this aspect for the metallurgical industry, which plays a significant role in the Ukrainian and world economy [26]. To contribute to the study of the problem, we use large metallurgical companies in Ukraine as our research sample.

The purpose of the paper is to evaluate the impact of corporate social responsibility on the company financial performance to determine the financial efficiency of socially responsible initiatives in the case for the metallurgical industry.

Research method and information used. Opensource information and results of expert assessment are the initial data for the analysis. When selecting metallurgical companies of Ukraine as a research object, we used financial and non-financial reporting, expert assessments, and statistical indicators to fill the information base in the context of perspectives

\section{Problem Solution}

Reducing costs for the non-production sphere, closing and separating socio-cultural facilities from the main company, in general, are typical for business practice of large companies in the metallurgical industry of Ukraine. Thus, it is obvious that the effective implementation of socially responsible initiatives is possible only if there is a confirmed relationship between them and the company financial performance.

We propose a methodology for evaluating the impact of corporate social responsibility on the company financial performance. The research methodology includes correlation and regression analysis with panel data techniques based on data from a socially oriented balanced scorecard (BSC) for a sample of four dominant market participants in the Ukrainian metallurgy in 2010-2018. The proposed methodology includes the following sequence of steps.

\subsection{Definition of the socially oriented BSC indicators}

In earlier research, we proposed a socially oriented BSC as a corporate social responsibility assessment methodology [25]. It contains a new composition of perspectives, objectives and performance indicators that fully characterize the metallurgical companies' activity (Table 1).

Table 1

Indicators of the socially oriented BSC

\begin{tabular}{|l|l|}
\hline Perspectives & Indicators \\
\hline perspective & Revenue growth \\
Return on assets \\
Return on sales \\
Autonomy ratio
\end{tabular}




\begin{tabular}{|l|l|}
\hline Perspectives & Indicators \\
\hline $\begin{array}{l}\text { Internal } \\
\text { process } \\
\text { perspective }\end{array}$ & $\begin{array}{l}\text { Investments in labor protection and } \\
\text { industrial safety growth } \\
\text { Investments in labor protection and } \\
\text { industrial safety in percentage of } \\
\text { total sales } \\
\text { Labor productivity } \\
\text { Specific energy consumption } \\
\text { Energy conservation growth rate } \\
\text { Energy conservation in percentage } \\
\text { of total costs }\end{array}$ \\
\hline $\begin{array}{l}\text { Relational } \\
\text { perspective }\end{array}$ & $\begin{array}{l}\text { Level of employees' satisfaction } \\
\text { Level of customers' satisfaction } \\
\text { Level of suppliers' satisfaction } \\
\text { Level of local community's } \\
\text { satisfaction } \\
\text { Participation in CSR programs }\end{array}$ \\
\hline
\end{tabular}

Sources: the authors' development

Designing a socially oriented BSC, we considered the availability and openness of the companies' non-financial data reporting, and the industry specificity when defining the environmental perspective's indicators.

\subsection{Standardization and aggregation of the socially oriented BSC}

The purpose of this step is to bring the companies' initial performance indicators to a single form suitable for further analysis and aggregation to the level of a single numerical characteristic of the company for each BSC perspective.

The indicators in the BSC perspectives are of equal importance.

Let $P=\{p\}$ be the set of perspectives considered within BSC.

The perspective's numerical characteristic can be defined by the average value of its constituent indicators:

$$
\bar{x}_{t}^{p}=\frac{\sum_{i=1}^{n_{p}} x_{i t}^{p}}{n_{p}}
$$

where $n_{p}$ is the number of indicators constituting the perspective $p ; I$ is index number in perspective; $t$ is time period; $x_{i t}^{p}$ is initial value of $x_{i}$ indicator of $p$ perspective in time period $t$.

However, in practice, the use of expression (1) is likely to give incorrect results due to the following reasons:

Different companies use different approaches for preparation and publication of their reports in cases where there is no standard reporting format. Therefore, the set of indicators constituting the BSC perspectives can be different for different companies.

An acceptable method for adjusting the impact of this reason is to calculate the perspective's value separately for each company, based on the actual set of available indicators.

Different indicators have a different range of changes, which leads to distortion of the results and an unintended increase in the significance of individual parameters. For example, if hypothetical perspective 1 consists of indicators $x_{1}^{1}$ и $x_{2}^{1}$, wherein $x_{1}^{1}$ varies in the interval $[-1 ; 1]$, and $x_{2}^{1}$ in the interval [-99;99], then the value of perspective, calculated by formula (1), as a result of their averaging, will be determined by $x_{2}^{1}$ indicator values by $99 \%$ and $x_{1}^{1}$ indicator values by only $1 \%$.

An acceptable method for adjusting the impact of this reason is the normalization of indicators to a standard interval.

Indicators in BSC can have a different direction of influence on the resulting assessment. Thus, it is obvious that the preferred direction of change for air pollution environmental indicators, measuring company's emissions, is to decrease. But the preferred direction for changing the level of waste disposal within the same perspective is to increase the indicator.

An acceptable adjustment method of this reason's impact is to consider the direction of the preferred change in indicators within the standardization procedure:

$$
\bar{x}_{t}^{p_{c}}=\frac{\sum_{i=1}^{n_{p_{c}}} \hat{x}_{i t}^{p_{c}}}{n_{p_{c}}}
$$

where $c$ is the company for which BSC perspective is calculated; $\quad \hat{x}_{i t}^{p_{c}}$ is the indicator's normalized value, which is calculated depending on the direction of the relationship between the change in the initial indicator's value and the perspective $y$.

A positive relationship between $x_{i}$ and $y$ means that increases in $x_{i}$ are associated with increases in $y$ (e.g. level of employees' satisfaction). For a positive relationship $\hat{x}_{i t}^{p_{c}}$ is calculated by the formula (3):

$$
\hat{x}_{i t}^{p_{c}}=\frac{x_{i t}^{p_{c}}-\min \left\{x_{i}\right\}}{\Delta\left\{x_{i}\right\}} ; \quad \uparrow x_{i} \Rightarrow \uparrow y
$$


A negative relationship between $x_{i}$ and $y$ means that increases in $x_{i}$ are associated with decreases in $y$ (e.g. waste volume per ton of steel). For a negative relationship $\hat{x}_{i t}^{p_{c}}$ is calculated by the formula (4):

$$
\hat{x}_{i t}^{p_{c}}=\frac{\left|x_{i t}^{p_{c}}-\max \left\{x_{i}\right\}\right|}{\Delta\left\{x_{i}\right\}} ; \quad \uparrow x_{i} \Rightarrow \downarrow y
$$

In (3) and (4) $\Delta\left\{x_{i}\right\}$ is the difference between the maximum and minimum value of the indicator $x_{i}$ for the entire period for all companies:

$$
\Delta\left\{x_{i}\right\}=\max \left\{x_{i}\right\}-\min \left\{x_{i}\right\} .
$$

The considered calculation method according to formulas (2) - (5) allows obtaining the aggregated values of BSC perspectives for each company in each period and it is universal. For its application, it is necessary to assess the relationship between the direction of change in indicators and the resulting value of the perspective. Since for most indicators in the BSC, this relationship is obvious, the analyst conducting the research can perform this assessment, and it does not require additional costs for expert evaluation

\subsection{Preliminary analysis of the relationship between perspectives of the socially oriented BSC}

We assess the level of corporate social responsibility by indicators of four perspectives, which are internal processes, learning and growth, environmental, and relational perspective. Building a model of the impact of corporate social responsibility perspectives on the financial perspective implies a preliminary analysis and assessment of the degree and direction of the relationship between the perspectives. Since such an analysis in the general case is rather complicated, nonlinear and can be carried out by various methods, it requires a separate stage in this research. As follows from (2), the input data for the analysis is a set of average values of the parameters for each perspective $\bar{x}_{t}^{p_{c}}$, which are interpreted as a numerical expression of the perspective $p$ at the company within period $i$.

Input data structure used in further analysis is shown in Table 2.
Table 2

Input data structure for the analysis of relationship in the socially oriented BSC

\begin{tabular}{|c|c|c|c|c|c|c|}
\hline Company & Year & $\mathrm{p}_{1}$ & $\mathrm{p}_{2}$ & $\mathrm{p}_{3}$ & $\mathrm{p}_{4}$ & $\mathrm{p}_{5}$ \\
\hline $\mathrm{c}_{1}$ & $\mathrm{t}_{1}$ & $\bar{x}_{1}{ }^{1}$ & $\bar{x}_{1}{ }^{2}$ &.. &.. &.. \\
\hline $\mathrm{c}_{1}$ & $\mathrm{t}_{2}$ & $\bar{x}_{2}{ }^{1}$ &.. &.. &.. &.. \\
\hline $\mathrm{c}_{1}$ & $\mathrm{t}_{3}$ &.. &.. &.. &.. &.. \\
\hline$\ldots$ &.. &.. &.. &.. &.. &.. \\
\hline $\mathrm{c}_{2}$ & $\mathrm{t}_{1}$ & $\bar{x}_{1}{ }^{2}$ &.. &.. &.. &.. \\
\hline $\mathrm{c}_{2}$ & $\mathrm{t}_{2}$ &.. &.. &.. &.. &.. \\
\hline $\mathrm{c}_{2}$ & $\mathrm{t}_{3}$ &.. &.. &.. &.. &.. \\
\hline$\ldots$ & &.. &.. &.. &.. &.. \\
\hline $\mathrm{c}_{3}$ & $\mathrm{t}_{1}$ &.. &.. &.. &.. &.. \\
\hline $\mathrm{c}_{3}$ & $\mathrm{t}_{2}$ & & & & & \\
\hline$\ldots$ &... & & & & & \\
\hline
\end{tabular}

Sources: the authors' development

The data structure shown in Table 2 is called panel one. Panel data are arrays in which each observation has two dimensions. One of the dimensions has a temporal interpretation (in our case, the year for which the observations were made), and the other dimension has a spatial interpretation (in our case, the company for which the perspective value is calculated).

Compared to a simple one-dimensional data structure, a panel structure has several advantages, since it allows to:

- improve the efficiency of estimates by separating observations in space and time;

- improve the economic interpretation of statistical analysis results;

- reduce errors arising from excessive data aggregation;

- trace the individual evolution of observed objects in time.

\subsection{Building a model for assessing financial perspective}

At this step, we built and evaluate various models of the dependence of the financial perspective $\left(p_{1}\right)$ on the rest perspectives $\left(p_{2}-p_{5}\right)$.

To ensure the possibility of using the dependent and independent variables notation generally accepted in economic statistics, we use the following notation:

$$
\begin{gathered}
y_{c t}=\bar{x}_{t}^{1_{c}} ; \\
x_{c t}^{1}=\bar{x}_{t}^{2_{c}} \ldots x_{c t}^{4}=\bar{x}_{t}^{5_{c}} .
\end{gathered}
$$


The use of regression models is traditional for panel data analysis. We select the following regression models.

1) Combined regression model.

In fact, it is a linear regression model, which in this case can be written as follows:

$$
y_{c t}=\alpha+\beta_{1} x_{c t}^{1}+\beta_{2} x_{c t}^{2}+\beta_{3} x_{c t}^{3}+\beta_{4} x_{c t}^{4}+v_{c t},
$$

where $\alpha$ is a free member; $\beta_{1}-\beta_{4}$ are coefficients for independent variables; $v_{\mathrm{ct}}$ is a random error.

The combined regression model does not take into account panel data peculiarities; therefore, it often shows not the best results. For consideration of these peculiarities, the assumption that the random error has the following structure is used:

$$
v_{c t}=u_{c}+\varepsilon_{c t}
$$

where $u_{c}$ are unobservable individual effects inherent in each of the observed objects; $\varepsilon_{c t}$ are residual disturbances.

Models with fixed and random effects demonstrate different approaches to the disclosure of formula (8).

2) Fixed effects model.

In this model, for each object, the value of unobservable individual effects $u_{c}$ is calculated, for which the method for determining the regression coefficients is adjusted:

$$
y_{c t}=u_{c}+\beta_{1} x_{c t}^{1}+\underset{\beta_{2} x_{c t}^{2}+\beta_{3} x_{c t}^{3}+\beta_{4} x_{c t}^{4}+\varepsilon_{c t},}{u_{c}=z_{c} \alpha} .
$$

The need to calculate an individual correction factor for each object limits the use of the fixed effects model when analyzing large data sets.

3) Random effects model.

This model assumes that the analyzed data sample is a part of a wider set of objects, therefore, the results obtained should be applicable outside the analyzed sample. Fixed effects model is inherently unsuitable for this purpose.

In random effects model, unobservable individual effects are considered statistically, based on the assumption of the randomness of these effects and their distribution:

$$
y_{c t}=\beta_{1} x_{c t}^{1}+\beta_{2} x_{c t}^{2}+\beta_{3} x_{c t}^{3}+\beta_{4} x_{c t}^{4}+\alpha+m_{c}+\varepsilon_{c t} .
$$

It should be noted that despite the existence of special statistical tests, there are also rules of thumb for selecting a specific panel data model. Thus, the combined model is used in cases where no individual differences are expected for research objects. In contrast, the fixed effects model assumes that each object is unique and cannot be considered because of random selection from the general population. This is typical for large companies or regions. The random effects model gives an acceptable result when analyzing objects selected from a large general population, e.g. small firms, households. This is a compromise model that avoids excessive complexity, but also enables to consider panel data peculiarities.

\section{Assessing the effectiveness and reliability of results}

We analyze the relationship between corporate social responsibility perspectives and financial performance indicators of the socially oriented BSC for a sample of four dominant market participants in the Ukrainian metallurgy. The objects of research are PJSC Azovstal Iron and Steel Works, PJSC Ilyich Iron \& Steel Works (MMKI), PJSC ArcelorMittal Kryvyi Rih (AMKR), as well as a large corporate structure - Metinvest Group, which is an integrated mining and metals company. PJSC Azovstal and PJSC MMKI are part of the international vertically integrated Metinvest Group.

When forming the initial data, we take as a basis the list of indicators given in Table 1. Some indicators of learning and growth perspective, environmental perspective, and perspective of internal processes within the framework of the socially oriented BSC are not available in the particular companies' reports. This could be due to both the specifics of their activities and corporate reporting standards. Using the proposed methodology for evaluating the impact of corporate social responsibility on the company financial performance allowed keeping the impact of the unique indicators on the overall assessment of BSC perspectives.

Based on the initial data, using expressions (2) (5), proposed in the above-described method of aggregating the values of the socially oriented BSC perspectives, an array is formed. After conversion to the panel structure, it takes the following form (Table 3).

Analysis of the main statistical characteristics of the data shows that they are evenly distributed, do not go beyond the boundaries of the interval $[0 ; 1]$, and no further actions is required to normalize the data. 
Table 3

Data for assessing the impact of corporate social responsibility on the company financial performance *

\begin{tabular}{|c|c|c|c|c|c|c|}
\hline Company & Year & $y$ & $x 1$ & $x 2$ & $x 3$ & $x 4$ \\
\hline \multirow{9}{*}{ AMKR } & 2010 & 0,721686 & 0,667884 & 0,378964 & 0,160307 & 0,757757 \\
\hline & 2011 & 0,741730 & 0,680659 & 0,386984 & 0,420446 & 0,778201 \\
\hline & 2012 & 0,478108 & 0,622772 & 0,427970 & 0,296365 & 0,749441 \\
\hline & 2013 & 0,532508 & 0,571567 & 0,523001 & 0,383650 & 0,457368 \\
\hline & 2014 & 0,612100 & 0,608162 & 0,538139 & 0,476898 & 0,533576 \\
\hline & 2015 & 0,673022 & 0,617863 & 0,482426 & 0,347801 & 0,541007 \\
\hline & 2016 & 0,684981 & 0,529525 & 0,427386 & 0,269756 & 0,517741 \\
\hline & 2017 & 0,734192 & 0,653838 & 0,525147 & 0,223517 & 0,647986 \\
\hline & 2018 & 0,802396 & 0,689261 & 0,465453 & 0,245485 & 0,567075 \\
\hline \multirow{9}{*}{ Azovstal } & 2010 & 0,587984 & 0,560444 & 0,407230 & 0,541476 & 0,727169 \\
\hline & 2011 & 0,514400 & 0,545332 & 0,335336 & 0,285692 & 0,685001 \\
\hline & 2012 & 0,191818 & 0,515095 & 0,494329 & 0,507701 & 0,615479 \\
\hline & 2013 & 0,219431 & 0,382361 & 0,534263 & 0,526843 & 0,534920 \\
\hline & 2014 & 0,570214 & 0,359183 & 0,545877 & 0,455280 & 0,612072 \\
\hline & 2015 & 0,405773 & 0,424590 & 0,550550 & 0,736641 & 0,713294 \\
\hline & 2016 & 0,566585 & 0,365085 & 0,630592 & 0,652435 & 0,587987 \\
\hline & 2017 & 0,732252 & 0,372212 & 0,640152 & 0,694931 & 0,744676 \\
\hline & 2018 & 0,618647 & 0,439526 & 0,812680 & 0,621325 & 0,778075 \\
\hline \multirow{9}{*}{ Metinvest } & 2010 & 0,616874 & 0,424545 & 0,399609 & 0,413036 & 0,725119 \\
\hline & 2011 & 0,770854 & 0,553446 & 0,312667 & 0,841639 & 0,732451 \\
\hline & 2012 & 0,512488 & 0,486377 & 0,548269 & 0,447077 & 0,516461 \\
\hline & 2013 & 0,513877 & 0,417869 & 0,549755 & 0,331688 & 0,493659 \\
\hline & 2014 & 0,437172 & 0,461458 & 0,561518 & 0,438124 & 0,600201 \\
\hline & 2015 & 0,105582 & 0,480593 & 0,585453 & 0,361120 & 0,463548 \\
\hline & 2016 & 0,378659 & 0,467403 & 0,415122 & 0,646160 & 0,443494 \\
\hline & 2017 & 0,543903 & 0,523959 & 0,390519 & 0,651649 & 0,751903 \\
\hline & 2018 & 0,625715 & 0,545023 & 0,326851 & 0,519834 & 0,739716 \\
\hline \multirow{9}{*}{ MMKI } & 2010 & 0,641580 & 0,482571 & 0,089072 & 0,263997 & 0,744872 \\
\hline & 2011 & 0,177371 & 0,512991 & 0,351268 & 0,258573 & 0,569311 \\
\hline & 2012 & 0,139862 & 0,481234 & 0,163677 & 0,268349 & 0,443439 \\
\hline & 2013 & 0,174770 & 0,466410 & 0,227598 & 0,253288 & 0,516372 \\
\hline & 2014 & 0,557732 & 0,442802 & 0,208895 & 0,484180 & 0,674223 \\
\hline & 2015 & 0,414852 & 0,521300 & 0,309009 & 0,510349 & 0,662699 \\
\hline & 2016 & 0,505516 & 0,728087 & 0,122512 & 0,429911 & 0,554345 \\
\hline & 2017 & 0,587198 & 0,609226 & 0,497594 & 0,497353 & 0,848135 \\
\hline & 2018 & 0,635895 & 0,565545 & 0,353615 & 0,421205 & 0,661025 \\
\hline
\end{tabular}

Source: Authors' calculations based on data from the companies' official web sites $[1 ; 2 ; 16 ; 21]$

where: $y$ - financial perspective; $x 1$ - learning and growth perspective; $x 2$ - environmental perspective; $x 3$ - internal process perspective; $x 4$ - relational perspective

Results of calculating simple correlation between parameters constituting the original data (without splitting on separate panels) are shown in Table 4. Table 4 shows that the strongest positive relationship is between financial $(y)$ and relational perspectives $\left(x_{4}\right)$. In statistical studies, a correlation coefficient of 0.4993 is considered a moderate correlation. The correlation between financial $(y)$ and learning and growth perspective $\left(x_{1}\right)$ is slightly weaker. The rest of correlation coefficients indicate a very weak linear relationship.

There is also a positive relationship between the year and the financial perspective. This suggests that during the period under review, an increase in 
companies' financial indicators was more often than a deterioration.

Further, we build models that explain the dependence of the financial perspective (dependent variable) on other perspectives (independent variables) within the framework of a socially oriented balanced scorecard.

Table 4

Correlation matrix of the socially oriented BSC perspectives

\begin{tabular}{|c|c|c|c|c|c|c|}
\hline & Year & $\mathbf{y}$ & $\mathbf{x 1}$ & $\mathbf{x 2}$ & $\mathbf{x 3}$ & $\mathbf{x 4}$ \\
\hline Year & 1 & & & & & \\
\hline $\mathbf{y}$ & 0.20 & 1 & & & & \\
\hline $\mathbf{x 1}$ & 0.02 & 0.36 & 1 & & & \\
\hline $\mathbf{x 2}$ & 0.34 & 0.10 & -0.31 & 1 & & \\
\hline $\mathbf{x 3}$ & 0.26 & 0.09 & -0.39 & 0.31 & 1 & \\
\hline $\mathbf{x 4}$ & -0.02 & 0.50 & 0.14 & -0.02 & 0.27 & 1 \\
\hline
\end{tabular}

Source: Authors' own calculations

Figure 1 shows the results of building a simple linear regression that does not consider the panel data structure. This model is the simplest one and it serves as a starting point for analyzing the effectiveness of more complex models [3;4].

Since all independent variables' values in the model above are normalized, we can consider their coefficients as indicators of the variables' importance. In Figure 1 it appears that coefficients for variables $x_{1}$ (learning and growth perspective) and $x_{4}$ (relational perspective) are the biggest. This corresponds to conclusions from the correlation analysis.

\begin{tabular}{|c|c|c|c|c|c|c|}
\hline $\begin{array}{l}5 \text { y } x 1 \times 2 \\
\text { Source | }\end{array}$ & $\begin{array}{ll}\mathrm{x} 4 & \\
& \text { Ss }\end{array}$ & df & MS & \multicolumn{2}{|r|}{$\begin{array}{l}\text { Number of obs } \\
F(4,31)\end{array}$} & 36 \\
\hline Model | & .480091754 & 4 & 120022939 & & & $\begin{array}{r}4.76 \\
0.0041\end{array}$ \\
\hline Residual | & .780857709 & 31 & .025188958 & & R-squared & 0.3807 \\
\hline & & & & & Adj R-squared & 0.3008 \\
\hline Total I & 1.26094946 & 35 & .036027128 & & Root MSE & .15871 \\
\hline y I & Coef. & Std. Err. & $t$ & $P>|t|$ & {$[95 \%$ cor } & if. Interval] \\
\hline $\mathrm{x} 1$ & .7563137 & .3194356 & 2.37 & 0.024 & .1048205 & 1.407807 \\
\hline$\times 2$ & .2585708 & .1889066 & 1.37 & 0.181 & -.1267067 & .6438483 \\
\hline$\times 3$ & .0683021 & .1977671 & 0.35 & 0.732 & -.3350465 & .4716508 \\
\hline$\times 4$ & .7255388 & .2577642 & 2.81 & 0.008 & .1998251 & 1.251252 \\
\hline _cons i & -.4647725 & .2386754 & -1.95 & 0.061 & -.9515543 & .0220092 \\
\hline
\end{tabular}

\section{Fig. 1. Simple linear regression model parameters}

Source: Authors' own calculations in STATA

The $\mathrm{R}^{2}$ coefficient of determination is the main indicator of regression model quality. In Figure 1 it is designated " $\mathrm{R}$-squared" due to peculiarities of the applied statistical analysis software STATA. The $\mathrm{R}^{2}$ value of 0,3807 means that the proportion of the variance for a dependent variable (financial perspective) is explained by independent variables in a regression model by $38,07 \%$. This is a rather low result. Building models, which consider the panel data structure, can improve it.

First, it is necessary to determine which of the panel regression models either fixed effects, or random effects is preferable in the case under consideration. We analyze this in terms of the sample ratio and the general population.

Below we consider the procedure for choosing between fixed and random effects models based on the Hausman test. For this purpose, we calculate the parameters of fixed effects panel regression (Figure 2), random effects panel regression (Figure 3), and the Hausman test (Figure 4).

The Hausman test allows us to test the plausibility of a hypothesis that deviations $u_{c}$ (expression 8) can be considered as random effects, with the alternative hypothesis that they are fixed effects.

The calculated $p$ value estimated at a significance level of 0.05 is the result. If the $p$ value is less than 0.05 , we reject the null hypothesis and conclude the need to consider observed deviations as fixed effects. Since Prob $>$ chi $2=0.03070$ in Figure 4, we should reject the random effects hypothesis and consider a fixed effects model.

Building such a model is in the same manner as a linear regression except one. Dummy variables are additionally introduced into the model. Their number corresponds to the panels' number. These variables take on the value 1 for one specific "own" panel and 0 in all other cases.

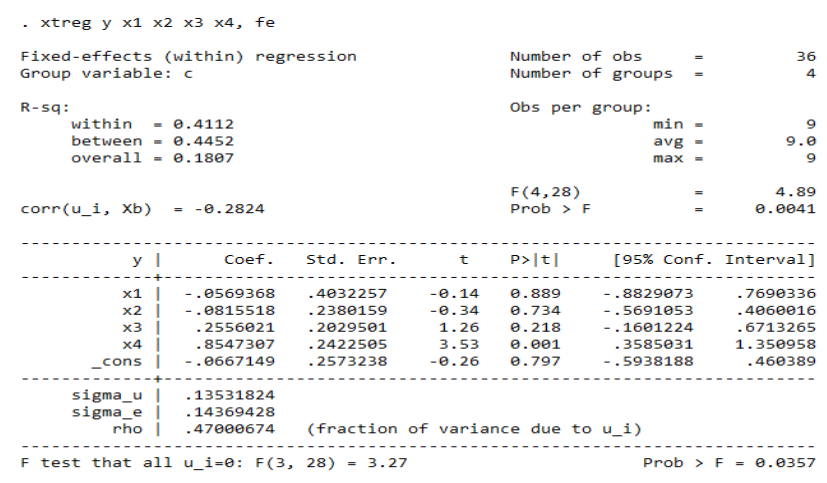

Fig. 2. Fixed effects panel regression parameters Source: Authors' own calculations in STATA 


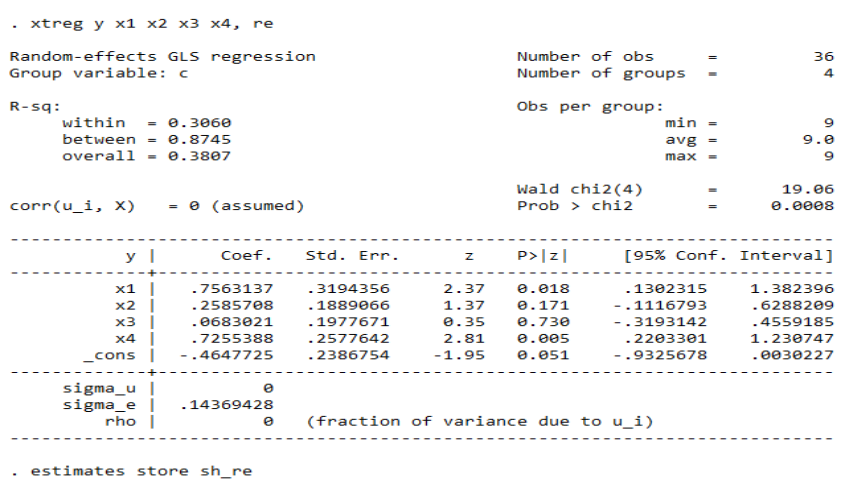

Fig. 3. Random effects panel regression parameters

Source: Authors' own calculations in STATA

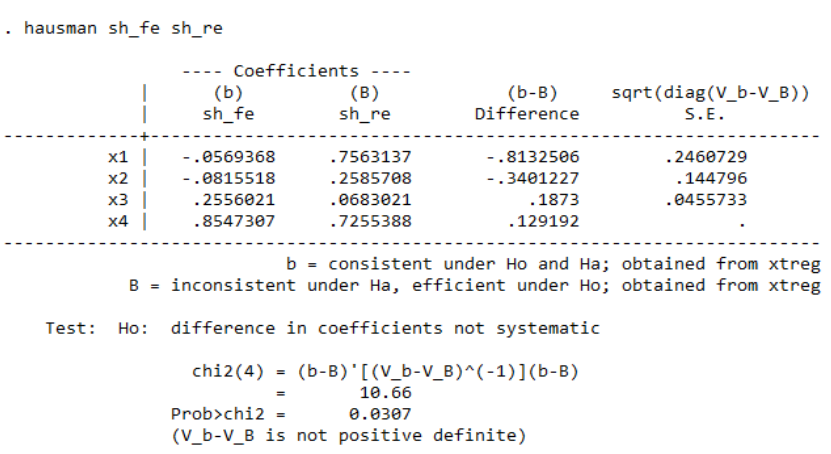

Fig. 4. Hausman test to compare fixed vs random effects panel regression

Source: Authors' own calculations in STATA

In the case, four data panels correspond to the number of companies under research. Therefore, we should introduce four dummy variables: $i$ - Ilyich Iron \& Steel Works; $a$ - Azovstal Iron and Steel Works; $m i$ - Metinvest Group; am - ArcelorMittal Kryvyi Rih.

Figure 5 shows the results of building a fixed effects panel regression model.

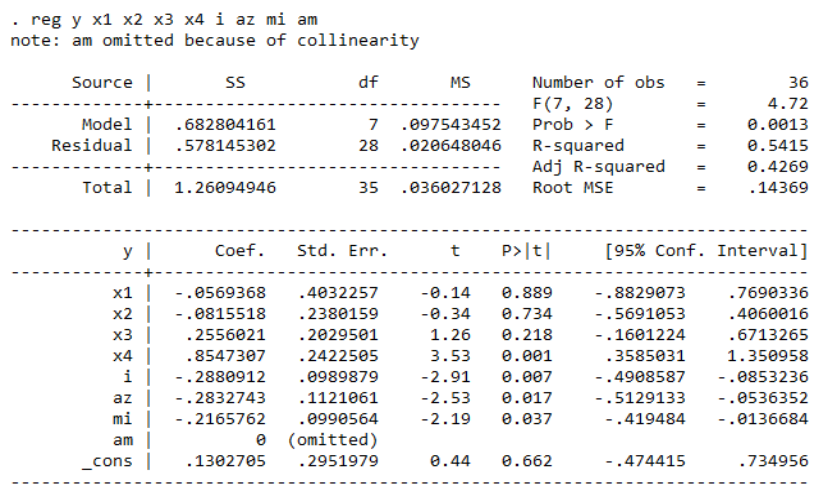

Fig. 5. Fixed effects panel regression model parameters

Source: Authors' own calculations in STATA
As follows from Figure 5, considering fixed effects made it possible to improve the $R^{2}$ coefficient of determination value from 0.3807 to 0.5415 for the simple linear regression model. This means that proportion of the variance for a dependent variable (financial perspective) is explained by $54,15 \%$ by the model, which is a statistically significant result. It should be noted that after fixed effects adjustment with dummy variables coefficients, coefficients of independent variables changed significantly compared to simple linear regression model.

For ease of comparison, Table 5 summarizes these coefficients from Figures 4, 5 and calculations of their change.

Table 5

Independent variables coefficients of different types of regression models

\begin{tabular}{|l|c|c|c|c|}
\hline $\begin{array}{c}\text { Independent } \\
\text { variables } \\
\text { coefficients }\end{array}$ & $\begin{array}{c}\text { Simple } \\
\text { linear } \\
\text { regressi } \\
\text { on } \\
\text { model }\end{array}$ & $\begin{array}{c}\text { Fixed } \\
\text { effects } \\
\text { regress } \\
\text { ion } \\
\text { model }\end{array}$ & $\Delta \beta$ & $\begin{array}{c}\text { Growth } \\
\text { rate } \beta\end{array}$ \\
\hline $\begin{array}{l}\text { Learning and } \\
\text { growth } \\
\text { perspective ( } \beta 1)\end{array}$ & 0,76 & $-0,06$ & $-0,81$ & $-107,5 \%$ \\
\hline $\begin{array}{l}\text { Environmental } \\
\text { perspective ( } \beta 2)\end{array}$ & 0,26 & $-0,08$ & $-0,34$ & $-131,5 \%$ \\
\hline $\begin{array}{l}\text { Internal process } \\
\text { perspective ( } \beta 3)\end{array}$ & 0,07 & 0,26 & 0,19 & $274,2 \%$ \\
\hline $\begin{array}{l}\text { Relational } \\
\text { perspective ( } \beta 4)\end{array}$ & 0,73 & 0,85 & 0,13 & $17,8 \%$ \\
\hline
\end{tabular}

Source: Authors' own calculations

Table. 5 shows that the coefficient of the variable "relational perspective" changes the least. Moreover, its importance has grown, which indicates a high degree of relationship between this perspective and company financial results.

The coefficient value of the variable "learning and growth perspective", which was the highest in the simple linear regression model, after fixed effects adjustment significantly decreases and even becomes negative. Thus, the analysis shows that this perspective is not strongly related with the financial one.

The coefficient value of the variable "ecological perspective" also significantly decreases and goes negative.

However, according to the table 5, there is an increase in the coefficient of the variable "perspective of internal processes". This variable is ranked second in importance in the fixed effects panel regression modeling. 
The research has revealed a strong and statistically significant relationship between the relational perspective and company financial results in the socially oriented balanced scorecard. This means that the costs for creating and maintaining a positive image of metallurgical companies are fully justified by improving their bottom line. In addition, initiatives to improve the perspective of internal processes are of great importance, that is, investments in labor protection, industrial safety, and energy conservation.

\section{Conclusion}

Determining the impact of socially responsible initiatives on the company financial performance is an important factor in introducing the concept of strategic corporate social responsibility management into the corporate governance system.

Based on the proposed methodology for assessing the impact of corporate social responsibility on corporate financial indicators, this paper analyzes the relationship between socially oriented and financial perspectives within the framework of a socially oriented BSC. The research methodology includes correlation and regression analysis with panel data techniques for a sample of four dominant market participants in the Ukrainian metallurgy: PJSC Azovstal Iron and Steel Works, PJSC Ilyich Iron \& Steel Works (MMKI), PJSC ArcelorMittal Kryvyi Rih (AMKR), and Metinvest Group.

The results of building linear and panel regression models with fixed and random effects are given. Considering panel effects made it possible to obtain more accurate estimates of coefficients for the regression model's independent variables compared to simple linear regression model.

The research has revealed a strong and statistically significant relationship between the relational perspective and company financial results in the socially oriented balanced scorecard. The relational perspective characterizes the level of satisfaction of various stakeholder groups with the company activities in the field of corporate social responsibility.

The research has made its contribution to confirm the importance of implementing corporate social responsibility programs and projects as a factor improving not only the company's image, but also the bottom line. In the long term, this leads to sustainable business development and the competitiveness growth.

The statistical methods are the main in the proposed methodology for assessing the impact of corporate social responsibility on corporate financial indicators because they are most fully documented in terms of assessing the reliability of results. Future research directions are comparing the effectiveness of statistical methods with alternative methods, e.g. data mining techniques, in terms of forecasting accuracy.

\section{References:}

[1] ArcelorMittal Kryvyi Rih (2021). Official web-site. Retrieved from: https://ukraine.arcelormittal.com/

[2] Azovstal Iron and Steel Works (2021). Official web-site. Retrieved from: https://azovstal.metinvestholding.com/

[3] Babenko, V., Panchyshyn, A., Zomchak, L., Nehrey, M., Artym-Drohomyretska, Z., Lahotskyi, T. (2021). Classical Machine Learning Methods in Economics Research: Macro and Micro Level Example. WSEAS Transactions on Business and Economics, Vol. 18, Art. \#22, pp. 209-217. https://doi.org/10.37394/23207.2021.18.22

[4] Babenko, V., Rayevnyeva, O., Zherlitsyn, D., Dovgal, O., Goncharenko, N., \& Miroshnichenko, T. (2020). Dynamics of forecasting the development of renewable energy technologies in Ukraine and Chile. International Journal of Industrial Engineering \& Production Research, 31(4), 587-596. https://doi.org/10.22068/ijiepr.31.4.587

[5] Bazillier, R. \& Vauday, J. (2014). CSR into (new) perspective. Foresight, 16(2), 176188. doi: https://doi.org/10.1108/FS-102012-0069

[6] Benavides-Velasco, C. A., QuintanaGarc?a, C., \& Marchante-Lara, M. (2014). Total quality management, corporate social responsibility and performance in the hotel industry. International Journal of Hospitality Management, 41, 77-87. doi: https://doi.org/10.1016/j.ijhm.2014.05.003

[7] Dawkins, C. (2014). The principle of good faith: Toward substantive stakeholder engagement. Journal of Business Ethics, 121, 283-295. doi: https://doi.org/10.1007/s10551-013-1697-z

[8] Endrikat, J., Guenther, E., \& Hoppe, H. (2014). Making sense of conflicting empirical findings: A meta-analytic review of the relationship between corporate environmental and financial performance. European Management Journal, 32(5), 735751. doi: https://doi.org/10.1016/j.emj.2013.12.004 
[9] Epstein, M. J., \& Rejc-Buhovac, A. (2014). Making sustainability work, best practices in managing and measuring corporate social, environmental, and economic impacts. Sheffield, UK: Greenleaf Publishing Limited.

[10] Erhemjamts, O., Li, Q., \& Venkateswaran, A. (2013). Corporate social responsibility and its impact on firms' investment policy, organizational structure, and performance. Journal of Business Ethics, 118, 395-412. doi: https://doi.org/10.1007/s10551-0121594-x

[11] Ferrero, I., Hoffman, M. W., \& McNulty, R. E. (2014). Must Milton Friedman embrace stakeholder theory? Business \& Society Review, 119(1), 37-59. doi: https://doi.org/10.1111/basr.12024

[12] Galant, A., \& Cadez, S. (2017). Corporate Social Responsibility and Financial Performance Relationship: A Review of Measurement Approaches. Economic Research - Ekonomska Istra?ivanja, 30(1), 676-693.

doi: https://doi.org/10.1080/1331677X.2017.131 3122

[13] Gangi, F., Mustilli, M., Varrone, N., \& Daniele, L.M. (2018). Corporate Social Responsibility and Banks' Financial Performance. International Business Research, 11(10), 42-58. doi: https://doi.org/10.5539/ibr.v11n10p42

[14] Gregory, A., \& Whittaker, J. (2013). Exploring the valuation of corporate social responsibility - A comparison of research methods. Journal of Business Ethics, 116(1), 1-20. doi: https://doi.org/10.1007/s10551-012-1465-5

[15] Helmig, B., Spraul, K., \& Ingenhoff, D. (2016). Under positive pressure: How stakeholder pressure affects corporate social responsibility implementation. Business \& Society, 55(2), 151-187. doi: https://doi.org/10.1177/0007650313477841

[16] Ilyich Iron \& Steel Works (2021). Official web-site. Retrieved from: https://ilyichsteel.metinvestholding.com/

[17] Kruger, P. (2015). Corporate goodness and shareholder wealth. Journal of Financial Economics, 115(2), 304-329. doi: https://doi.org/10.1016/j.jfineco.2014.09.00 8

[18] Madorran, C., \& Garcia, T. (2016). Corporate Social Responsibility and Financial Performance: The Spanish Case.
Revista de Administra??o de Empresas, 56(1), 20-28. doi: http://dx.doi.org/10.1590/S0034759020160103

[19] Mahenthiran, S., Terpstra-Tong, J. L. Y., Terpstra, R., \& Rachagan, S. (2015). Impact of executive citizenship and organizational commitment on corporate social responsibility. Social Responsibility Journal, 11(2), 387-402. doi: https://doi.org/10.1108/SRJ-04-2013-0040

[20] Mansell, S. (2013). Shareholder theory and Kant's 'duty of beneficence'. Journal of Business Ethics, 117, 583-599. doi: https://doi.org/10.1007/s10551-012-1542-9

[21] Metinvest (2021). Official web-site. Retrieved from: https://metinvestholding.com/

[22] Michelon, G., Boesso, G., \& Kumar, K. (2013). Examining the link between strategic corporate social responsibility and company performance: An analysis of the best corporate citizens. Corporate Social Responsibility and Environmental Management, 20(2), 81-94. doi: https://doi.org/10.1002/csr.1278

[23] Miller, D. P. (2016). The Relationship between Corporate Social Performance and Financial Performance. Walden Dissertations and Doctoral Studies. Retrieved from https://scholarworks.waldenu.edu/dissertatio $\mathrm{ns} / 2563$

[24] Mints, A., Kamyshnykova, E. (2019) Methodological approach for assessing corporate social responsibility on the basis of balanced scorecard. Organizationaleconomic mechanism of management innovative development of economic entities. Przeworsk: WSSG, 2019. Vol. 3.

[25] Moser, D.V., \& Martin, P.R. (2012). A broader perspective on corporate social responsibility research in accounting. The Accounting Review, 87(3), 797-806. doi: https://doi.org/10.2308/accr-10257

[26] Perevozova, I., Daliak, N., Babenko, V. (2019). Modeling of Financial Support for the Competitiveness of Employees in the Mining Industry. CEUR Workshop Proceedings, vol. 2422, pp. 444-454. URL: http://ceur-ws.org/Vol-2422/paper36.pdf

[27] Przychodzen, J. \& Przychodzen, W. (2013) Corporate sustainability and shareholder wealth, Journal of Environmental Planning and Management, 
56(4), 474-493. doi: https://doi.org/10.1080/09640568.2012.685 927

[28] Saxena, M., \& Kohli, A. S. (2012). Impact of corporate social responsibility on corporate sustainability: A study of the Indian banking industry. IUP Journal of Corporate Governance, 11(4), 39-54. Retrieved from https://www.semanticscholar.org/paper/Imp act-of-Corporate-Social-Responsibility-onA-of-Saxena-

Kohli/98d1743b514e02574ed515223f1bf28 b40d0a24e

[29] Schwartz, M. S., \& Saiia, A, D. (2012). Should firms go 'beyond profits'? Milton Friedman versus broad CSR1. Business \& Society Review, 117(1), 1-31. doi: https://doi.org/10.1111/j.14678594.2011.00397.x

[30] Shahzad, A.M., \& Sharfman, M.P. (2017). Corporate social performance and financial performance: Sample-selection issues. Business \& Society, 56(6), 889-918. doi: https://doi.org/10.1177/0007650315590399

[31] Soana, M. G. (2011). The relationship between corporate social performance and corporate financial performance in the banking sector. Journal of Business Ethics, 104, 133-148. doi: https://doi.org/10.1007/s10551-011-0894-x

[32] Sun, L. (2012). Further evidence on the association between corporate social responsibility and financial performance. International Journal of Law and Management, 54(6), 472-484. doi: https://doi.org/10.1108/1754243121128195 4

[33] Youn, H., Hua, N., \& Lee, S. (2015). Does size matter? Corporate social responsibility and firm performance in the restaurant industry. International Journal of Hospitality Management, 51, 127-134. doi: https://doi.org/10.1016/j.ijhm.2015.09.008.

\section{Contribution of individual authors to the creation of a scientific article (ghostwriting policy)}

\footnotetext{
Author Contributions:

Aleksey MINTS has designed the methodology.

Evelina KAMYSHNYKOVA has created models

Dmytro ZHERLITSYN has carried out the econometrics modelling.
}

Katerina BUKRINA has implemented the model on the statistical data.

Anna BESSONOVA has been responsible for the Statistics.

Follow: www.wseas.org/multimedia/contributorrole-instruction.pdf

\section{Sources of funding for research presented in a scientific article or scientific article itself \\ Report potential sources of funding if there is any}

\section{Creative Commons Attribution}

\section{License 4.0 (Attribution 4.0 \\ International, CC BY 4.0)}

This article is published under the terms of the Creative Commons Attribution License 4.0 https://creativecommons.org/licenses/by/4.0/deed.en _US 